\title{
Melisa Okičić
}

\section{ZAŠTO NAM JE TEŠKO USVOJITI ENGLESKE SLOŽENE IMENICE: NEKOLIKO ZAPAŽANJA IZ TEORIJE I PRAKSE}

Rad se bavi propitivanjem razloga zbog kojih je studentima engleskog, kojima je bosanski/hrvatski/srpski maternji jezik, teško usvojiti engleske složene imenice. Ovaj problem pokušao se pojasniti iz ugla usporedbe morfologije imenica i padežnih nastavaka u engleskom i bosanskom/hrvatskom/srpskom jeziku, zatim, pojašnjavanjem uloge negativnog transfera u procesu usvajanja stranog jezika, te analize strukture prevodnih ekvivalenata. Diskusija o ovoj temi ukazala je na to da produktivnost slaganja u velikoj mjeri zavisi od toga koliko je morfologija imenica nekog jezika kompleksna. Drugim riječima, što je kompleksnija morfologija imenica, to je stepen produktivnosti slaganja niži. Analiza prevodnih ekvivalenata također je ukazala na to da je jedan od ključnih razloga ovog problema to da studenti riječi i fraze sa maternjeg jezika (L1) obično prevode riječ - po - riječ na engleski (L2). Ovo je direktno uslovljeno činjenicom da u bosanskom/hrvatskom/srpskom jeziku složenice nisu visokofrekventne riječi, kao što je to slučaj s engleskim. Jedan od najvažnijih zaključaka ide u korist prijedloga da se ovakve i slične kontrastivne jezičke razlike podučavaju uz upotrebu pažljivo osmišljenih smjernica i pojašnjenja na maternjem jeziku.

Ključne riječi: slaganje, složene imenice, prevodni ekvivalenti, maternji jezik, produktivnost

\section{UVOD}

U engleskom jeziku složenice su visokofrekventne riječi i čine poprilično veliki dio cjelokupne leksike ovog jezika, pri čemu se složene imenice ističu kao ekstremno produktivne. Primjeri takvih složenica u engleskom jeziku bili bi doghouse, moonlight, raindrop, face mask, coronavirus, London Fashion Week, Assistant Director, itd. ${ }^{1}$

\footnotetext{
${ }^{1}$ Ovaj rad nije zamišljen kao studiozna lingvistička studija i stoga će se, kada je riječ o lingvističkim osobinama složenica, te osobine u ovom radu navesti informativno, bez ulaženja u detaljne analize što, svakako, može biti predmet drugih radova. op. a.
} 
Sa druge strane, slaganje u bosanskom/hrvatskom/srpskom jeziku nije osobito produktivan način tvorbe. Kao posljedica takve situacije, ni složenice, a samim tim ni složene imenice, $u$ trima jezicima nisu zastupljene $u$ onom omjeru kao što je to slučaj s engleskim. Primjeri složenica u bosanskom/ hrvatskom/srpskom jeziku bili bi: ribolov, strahopoštovanje, niskogradnja, samopouzdanje, srednjoškolac, poslodavac, vatrogasac, itd. ${ }^{2}$

Ovakva razlika između engleskog i bosanskog/hrvatskog/srpskog predstavlja veoma važnu kontrastivnu lingvističku činjenicu, ali i veliki izazov za sve one koji se bave podučavanjem engleskog jezika. ${ }^{3}$ Radeći dugi niz godina kao predavač na Odsjeku za anglistiku Filozofskog fakulteta Univerziteta u Sarajevu, kao veoma upadljivo ističe se zapažanje da studenti kojima je bosanski/hrvatski/srpski maternji prilikom usmenog i/ili pismenog izražavanja veoma rijetko upotrebljavaju engleske složene imenice. To je naročito slučaj ukoliko se radi o izrazima koji za studenta predstavljaju novi vokabular. Naprimjer, pomoćnik direktora često se izražava kao Director's Assistant ili Assistant to Director (umjesto Assistant Director); Centar za prevenciju nasilja u porodici se obično izražava kao Centre for the Prevention of Violence in Family (umjesto ${ }^{4}$ Family Violence Prevention Centre i sl. ${ }^{5}$

Budući da se o problemu usvajanja engleskih složenica općenito na prostoru Bosne i Hercegovine ne govori baš mnogo, ovakva situacija bila je i ključni motiv za ideju ovog rada koji je zamišljen kao početni u nizu planiranih budućih istraživanja na ovu temu. S obzirom na to da se tema ovog rada eksplicitno bavi engleskim složenim imenicama, rad polazi od sljedećih istraživačkih pitanja:

IP1: Koji razlozi utiču na postojanje različitog stepena produktivnosti slaganja u engleskom i bosanskom/hrvatskom/srpskom jeziku?

${ }^{2}$ Primjeri preuzeti iz Jahić - Halilović - Palić, 2004, str. 322.

${ }^{3}$ Pri čemu se ovdje misli na predavače engleskog jezika kojima je bosanski/hrvatski/ srpski maternji jezik i koji podučavaju učenike/polaznike kursa/studente kojima je jedan od tri spomenuta jezika maternji. op. a.

${ }^{4}$ Naravno da su i opisni primjeri tačni, ali ovdje je fokus na (ne)korištenju složenih imenica. op. a.

${ }^{5}$ Uz napomenu da studenti ovu vrstu poteškoće obično ne pokazuju ukoliko su u pitanju riječi (složenice) koje predstavljaju već ranije poznat vokabular, poput: lipstick (ruž za usne), snowstorm (snježna oluja), homework (domaći zadatak/domaća zadaća) i sl. op. a. 
IP2: Na koji način različit stepen produktivnosti slaganja utiče na problem usvajanja engleskih složenih imenica?

IP3: Da li bi prilikom podučavanja engleskih složenih imenica bilo korisno uključiti i pojašnjenja na maternjem jeziku?

Rad je organiziran na sljedeći način. Nakon uvoda slijedi kraći osvrt na najvažnije teorijske postavke definiranja i analize složenica u engleskom i bosanskom/hrvatskom/srpskom jeziku, nakon čega slijedi analiza prevodnih ekvivalenata. Rad završava zaključkom u kojem su navedene neke od najvažnijih preporuka.

\section{NEKOLIKO NAPOMENA O SLOŽENICAMA, ANALIZI I TERMINOLOGIJI}

Kao što je općepoznato, o složenicama se u lingvističkoj literaturi govori veoma dugo. Zavisno od jezika do jezika, odnosno od niza faktora koji utiču na to da li su složenice u nekom jeziku manje ili više zastupljene, za njihov opis, analizu i interpretaciju koristi se različita gramatička terminologija. To je, naravno, sasvim logično, ali ovo je veoma važno razumjeti na samom početku, budući da upravo način na koji se složenice nekog jezika opisuju mnogo govori o morfologiji jednog jezika, što je i ključ za razumijevanje svih problema iz ove oblasti, o čemu će biti riječi u nastavku.

\section{O DEFINICIJI I ANALIZI SLOŽENICA U ENGLESKOM JEZIKU}

U engleskom jeziku složenica se najčešće definira kao riječ koja nastaje kombinacijom (najčešće) dvije riječi koje tvore novu. To se najbolje vidi iz nekoliko definicija koje, u svrhu ilustracije, navodimo u nastavku.

"Compounding or composition, is, roughly speaking, the process of putting two words together to form a third." (Bauer, 1983, str. 11)

"Compounding is a process by which a compound lexeme is derived from two or more simpler lexemes.” (Matthews, 1991, str. 82)

„A compound is a word which consists of two or more words." (Fabb, 1998, str. 66) 
"It is one of the major processes in language for the formation of new words." (Olsen, 2000a, str. 897)

"A compound consists of two lexemes that are joined together (called compound members).” (Haspelmath, 2002, str. 85)

"Compound is the formation of a new lexeme by adjoining two or more lexemes.” (Bauer, 2003, str. 40)

"Compounding (also called composition) is the combination of two words to form a new word." (Plag, 2003, str. 133)

Dalje, u engleskoj literaturi složenice se najčešće analiziraju na tri nivoa. Prvi je morfološki, te se, u tom pogledu, govori o strukturi složenice koja uvijek ima dvije "sastavnice" (engl. constituents). Važno je istaći da se pod "glavnom sastavnicom" naziva "upravni član složenice" (engl. head) koji se u većini engleskih složenica nalazi na desnom mjestu (engl. right-headed compounds). ${ }^{6}$ Za prikaz strukture uvijek se koriste uglaste zagrade, naprimjer: ${ }^{7}$

\section{$[\mathrm{N}] \mathrm{N} \&[\mathrm{~N}] \mathrm{N} \rightarrow[[\mathrm{N}] \mathrm{N}[\mathrm{N}] \mathrm{N}] \mathrm{N}$ \\ $[$ finger $] \mathrm{N} \&[$ print $] \mathrm{N}] \rightarrow[[$ finger $] \mathrm{N}[$ print $] \mathrm{N}] \mathrm{N}$}

Drugi kriterij je sintaksički, pri čemu je posebno važno napomenuti da se ovdje ne radi o sintaksičkoj interpretaciji na nivou rečenice, već o vrsti (porijeklu) upravnog člana složenice. Prema ovom kriteriju, složenice se dijele na korijenske (engl. root) i sintetičke (engl. synthetic). Pod korijenskim složenicama podrazumijevaju se složenice kod kojih se na mjestu upravnog člana pojavljuje prosti (nederiviran) leksem. Primjer jedne korijenske složene imenice bio bi bedtime (vrijeme za spavanje), a struktura se može predstaviti na sljedeći način: [bed]N \& [time]N $\rightarrow$ [[bed]N [time] $\mathrm{N}] \mathrm{N}>$ bedtime (time (imenica) nije derivirana iz neke druge vrste riječi).

Takozvane "sintetičke" složenice su one kod kojih se na mjestu upravnog člana pojavljuje leksem koji je deriviran iz neke druge vrste riječi,

\footnotetext{
${ }^{6}$ Postoje i složenice s upravnim članom na lijevoj strani, kao naprimjer, Secretary General, ali su ti primjeri mnogo rjeđi. op. a.

${ }^{7}$ Pri čemu N označava riječ "noun” (engl. imenica); znak \& označava povezivanje, spajanje, a “ $\rightarrow$ ” ishod (vrstu složenice). Za više informacija vidi Haspelmath, 2002.
} 
naprimjer, imenica izvedena iz glagola. Primjer jedne sintetičke složenice bio bi a songwriter, a struktura se može predstaviti na sljedeći način: [song]N \& [writer]N $\rightarrow$ [[song] $\mathrm{N}$ [writer]N]N > songwriter (writer je imenica derivirana iz glagola to write $>$ writer).

Treći kriterij je semantički. ${ }^{8}$ Ovisno od toga da li se značenje složenica može (ili ne može) "dekodirati" na osnovu značenja njenih sastavnica, sve engleske složenice dijele se u grupu endocentričnih (engl. endocentric) i egzocentričnih (engl. exocentric). Najkraće rečeno, kod endocentričnih složenica se semantički centar ili lokus nalazi unutar, a kod egzocentričnih izvan složenice (za više informacija vidi: Haspelmath, 2002; Lieber, 2004; Booij, 2005; Scalise i Guevara, 2006). Primjer endocentrične složenice bio bi: dog + house $>$ a house for dogs $>$ kućica za pse (značenje je moguće interpretirati na osnovu sastavnica složenice), a primjer egzocentrične $a$ busboy (pomoćnik konobara; (obično) mlađa osoba koja čisti stolove u restoranu nakon što gosti odu) jer značenje nije moguće interpretirati na osnovu značenja sastavnica složenice, cf. bus (autobus) ${ }^{9}+$ boy (dječak) $>$ ?

\section{O DEFINICIJI I ANALIZI SLOŽENICA U BOSANSKOM / HRVATSKOM / SRPSKOM JEZIKU}

Pristup analizi složenica u bosanskom/hrvatskom/srpskom jeziku je, u odnosu na engleski, samo donekle sličan. Jedna od najupečatljivijih razlika ogleda se u samoj definiciji te u nastavku navodimo nekoliko definicija.

Slaganje je tvorbeni način kojim od dviju riječi nastaje jedna - složenica. Između dvaju dijelova složenice obično se nalazi interfiks (spojnik; najčešće je to basno-o-pisac, brod-o-vlasnik, crn-o-oka) (...) ali ima složenica $\mathrm{i}$ bez interfiksa (nulti interfiks, spojnik nula, -0-: Bosna film, duhankesa, fotoaparat, raspikuća). Pritom je važna motivacija, tj. jesu li to dva

\footnotetext{
${ }^{8}$ Ova vrsta podjele složenica je i najstarija, s obzirom na to da još datira iz vremena sanskrta čiji su govornici još u ono vrijeme primijetili da određeni spojevi riječi ne znače isto što i značenja riječi od kojih su postale, kao, naprimjer, bahuvrihi što doslovno znači puno riže, a zapravo veoma bogat (Riđanović, 1998, str. 160)

${ }^{9}$ Bez ulaženja u etimologiju riječi, ovaj primjer služi samo za ilustraciju "bukvalnog" značenja u kontekstu upotrebe najčešćeg značenja riječi (sastavnica) u savremenom engleskom jeziku. op. a.
} 
"ravnopravna" pojma ili jedan jedinstven, ili pak zavisna sintagma. (Jahić - Halilović - Palić, 2000, str. 307)

(...) pored derivacije u užem smislu, postoji i slaganje dvaju ili više korijenskih morfema u novu riječ (Jadran-film, žut-o-zelen), s dodatnim afiksima ili bez njih. (Riđanović, 1998, str. 159)

Složenica je ona tvorenica koja je nastala slaganjem, a motivisana je dvijema riječima." (Barić, 1995, str. 296)

Postoji mišljenje da su složenice one tvorenice koje su motivisane sa dve reči, bilo da su te reči punoznačne ili ne. (Vukičević, 1995, str. 56)

Slaganje je takav način tvorbe u kojoj nova riječ nastaje od osnova dviju ili više riječi, o dviju ili više osnova. (Babić, 1986, str. 30)

Svaka složenica (složena reč) sastavljena je od osnova dveju reči. (...) Između prvog i drugog dela, većina složenica ima spojni vokal, kao znak međusobne veze. Taj vokal je obično -o-, kao u ribolov, poljoprivreda, spasonosan, rukovoditi, ređe -e- kao u oceubica, očevidan, svojeručan. (Klajn, 2005, str. 211)

Ukoliko uporedimo ove definicije s definicijama na engleskom jeziku, sasvim je očito da definicije na bosanskom/hrvatskom/srpskom jeziku mnogo rjeđe koriste termin "riječ", a mnogo više termin "osnova". ${ }^{10}$ Zašto je ovo bitno, pojasnit ćemo u nastavku.

Što se tiče pristupa analizi složenica, u lingvističkoj literaturi na bosanskom/hrvatskom/srpskom jeziku najčešće se govori iz ugla "hijerarhije pojmova", odnosno "ravnopravnih pojmova" unutar složenice (Jahić - Halilović - Palić, 2005, str. 307), te identifikacije prve sastavnice složenice. (Vidi: Barić et al., 1995; Klajn, 2002; Babić, 1986), pa se tako govori, naprimjer, o složenim imenicama s imeničkom/zamjeničkom/brojevnom itd. osnovom u prvom dijelu. Termin "upravni član složenice" ne koristi se za potrebe opisa u literaturi na bosanskom/hrvatskom/srpskom jeziku (kao što je to slučaj s engleskim).

I na kraju, kada je riječ o semantičkoj analizi, u literaturi na bosanskom/ hrvatskom/srpskom jeziku najčešće se govori iz ugla subordiniranih i

\footnotetext{
${ }^{10} \mathrm{Uz}$ napomenu da se u bosanskom, hrvtskom i srpskom jeziku pravi razlika između složenica (koje najčešće imaju spojni vokal i sraslica poput, naprimjer, "kuće vlasnik" > "kućevlasnik" (Jahić-Halilović-Palić, 2004, str. 308).
} 
koordiniranih (Marković, 2012, str. 67-68). Kod suboordiniranih jedna sastavnica ističe se kao glavna, a druga je podređena (subordinirana), naprimjer suhozid. Koordinativne složenice su one kod kojih su obje sastavnice semantički ravnopravne (grad-država, gluhonijem). ${ }^{11}$

\section{ZAŠTO SU SLOŽENE IMENICE IZUZETNO PRODUKTIVNE U ENGLESKOM JEZIKU?}

Odgovor na ovo pitanje na indirektan način proizilazi iz svega onoga što smo do sada rekli o složenicama u engleskom i bosanskom/hrvatskom/ srpskom jeziku, ali ćemo ovu temu ovdje, ipak, malo detaljnije obraditi. Prvo, u odnosu na bosanski/hrvatski/srpski, padežni sistem engleskog jezika je u ogromnoj mjeri reduciran. Da bismo ovo razumjeli, važno je istaći i sljedeće. Kada je riječ o padežnom sistemu engleskog jezika, u stručnoj lingvističkoj literaturi i danas se vode diskusije o načinu na koji bi se padežni sistem engleskog jezika trebao analizirati, naročito u pogledu identifikacije broja padeža. U tom smislu, važno je istaći da je u odnosu na savremeni engleski jezik, staroengleski bio jezik s mnogo bogatijim morfološkim sistemom, naročito kada je riječ o flektivnim nastavcima. U staroengleskom imenice su u padežnoj paradigmi imale flektivne nastavke za padeže nominativ, vokativ, akuzativ, genitiv i dativ. Međutim, kroz historijski razvoj jezika došlo je do iščezavanja velikog broja flektivnih nastavaka općenito, a u padežnoj paradigmi kakvu imamo danas "preživio" je samo nastavak za padež genitiva (Eckersly i Eckersly, 1997, str. 45). S tim u vezi, danas neki autori, naprimjer, Quirk et al. (2004, str. 318) ističu da se u engleskom jeziku treba govoriti o samo dvije vrste oblika riječi u padežnoj paradigmi, tj. nemarkiranom (boy, sg. vs. boys, pl.) i markiranom genitivnom obliku (boy's). ${ }^{12}$ Sa druge strane, Katamba (1993) smatra da je padežni sistem engleskog jezika bez "vidljivo realiziranih" (engl. not overtly marked) flektivnih nastavnika na površini, osim u slučaju padeža genitiva. Katamba također ističe da se realizacija nekih drugih padeža, kao što je to slučaj s dativom i instrumentalom u engleskom jeziku, ostvaruje isključivo kombinacijom imenice s prijedlozima, i to for/to za dativ, a with

\footnotetext{
${ }^{11} \mathrm{Za}$ više informacija vidi Marković, 2012.

${ }^{12}$ We shall distinguish between two cases of nouns: the unmarked COMMON CASE (eg: boy in the singular, boys in the plural) and the marked GENITIVE CASE (eg: boy's in the singular, boys' in the plural) (Quirk et al., 2004, str. 318).
} 
za instrumental (str. 21). ${ }^{13}$ Ukoliko sve ovo što smo rekli maksimalno pojednostavimo, padežnu paradigmu savremenog engleskog jezika možemo predstaviti na sljedeći način:

Jedina
Nominativ: a boy
Genitiv: a boy's
Dativ: to a boy
Akuzativ: a boy
Instrumental: with a boy

Množina

Nominativ: boys

Genitiv: boys'

Dativ: to boys

Akuzativ: boys

Instrumental: with boys

Kao što se može zapaziti, s obzirom na to da imenica (neznanto) mijenja svoj oblik samo u padežu genitiva, zbog takve situacije u engleskom jeziku se imenice doslovno "lijepe jedna za drugu" i s velikom lakoćom tvore složenicu. Primjeri takvih imenica/složenica bili bi kao što slijedi:

$$
\begin{aligned}
& \text { dog }+ \text { house }>\text { doghouse, song }+ \text { writer }>\text { songwritter, honey }+ \text { moon }> \\
& \text { honeymoon, man }+ \text { hole }>\text { manhole, blood }+ \text { stream }>\text { bloodstream, fire } \\
& + \text { man }>\text { fireman, man }+ \text { servant }>\text { manservant }{ }^{14}
\end{aligned}
$$

Međutim, posebno je važno istaći da engleske složene imenice ne nastaju kombinacijom samo dvije, već tri, četiri i više imenica. Ovo je izuzetno važno spomenuti jer razlog za takvu situaciju u engleskom jeziku itekako postoji. Pored ranije opisane situacije s imenicama i odsustvom flektivnih nastavaka, kao što ističe Riđanović (2007), u engleskom jeziku ne postoji ni mnogo "pravih" (nederiviranih) pridjeva koji se mogu upotrijebiti kao atributi kojima se označava svojstvo imenice (naprimjer: crven, visok, mlad, sretan). Upravo zbog toga, "kad god engleski jezik treba pridjev, engleski uposli imenicu” (Riđanović, 2007, str. 144). Tipičan primjer jedne takve složenice koja nastaje nizom od tri imenice je: London + Fashion + Week $>$ London Fashion Week, gdje se, naprimjer, u sastavu složenice pojavljuje

\footnotetext{
${ }^{13}$ English case is not generally overtly marked by inflection in nouns. A noun has the same form regardless of whether it is subject or object. Only pronouns are inflected for case. (...) In English the preposition with is commonly used for this purpose as in $\mathrm{He}$ chopped the tree down with an axe. The use of a preposition to mark the instrument is common. (Katamba, 1993, str. 21).

${ }^{14}$ Zanimljivo je uočiti da ovakve slučajeve bhs tretira primjerima sraslica, a ne složenica. Sraslice, kao ni složenice, nisu produktivne tvorenice u bosanskom/hrvatskom/srpskom jeziku. op. a.
} 
imenica London, i to isključivo zato što engleski nema -ski/-ški pridjeva, za razliku od bosanskog/hrvatskog/srpskog (cf. London > london-ski). ${ }^{15}$

\title{
ZAŠTO SLOŽENE IMENICE NISU PRODUKTIVNE U BOSANSKOM/HRVATSKOM/SRPSKOM JEZIKU?
}

U bosanskom/hrvatskom/srpskom jeziku situacija sa složenim imenicama je, u odnosu na engleski, dijametralno suprotna. Prvo, za razliku od engleskog, kao što je općepoznato, bosanski/hrvatski/srpski ima sedam padeža. Drugo, rod, broj i padež su u padežnoj paradigmi u trima jezicima "kumulativno izražene" flektivnim nastavkom (Riđanović, 2012, str. 365), što je velika razlika u odnosu na engleski jezik. I na kraju, imenice u padežnoj paradigmi u manjoj ili većoj mjeri mijenjaju svoj oblik. Naprimjer: ${ }^{16}$

\author{
Jednina \\ Nominativ: nok-a-t \\ Genitiv: nokt-a \\ Dativ: nokt-u \\ Akuzativ: nok-a-t \\ Vokativ: nokt-e \\ Instrumental: nokt-u \\ Lokativ: nokt-om
}

\author{
Množina \\ Nominativ: nokt-i \\ Genitiv: nok-a-t-a \\ Dativ: nokt-ima \\ Akuzativ: nokt-e \\ Vokativ: nokt-i \\ Instrumental: nokt-ima \\ Lokativ: nokt-ima
}

U odnosu na engleski, bosanski/hrvatski/srpski mnogo je bogatiji kada je riječ o pridjevima, bez obzira na to da li se radi o pravim ("nederiviranim") ili deriviranim pridjevima. Kao što smo ranije spomenuli, jedan od izuzetno frekventnih derivacionih nastavaka je nastavak -ski/ -ški (naprimjer londonski), dok engleski takvih pridjeva uopće nema. Zbog takve situacije, u bosanskom/hrvatskom/srpskom jeziku nije uobičajena praksa upotrebe imenice kao pridjeva (atributa). ${ }^{17}$

\footnotetext{
${ }^{15} \mathrm{~S}$ obzirom na temu ovog rada, nećemo ulaziti u detalje i opis kriterija na temelju kojih se tvorenica smatra složenicom. op. a.

${ }^{16}$ U svrhu ilustracije navedeni su oblici samo za jedninu. Preuzeto iz Barić et al., 1995, str. 105.

${ }^{17}$ Međutim, ne smiju se zanemariti primjeri poput Sarajevo Film Festival (umjesto: Sarajevski festival filma ili Sarajevski filmski festival), Avaz Business Centar, Tepih Centar, Bosna Sunce Osiguranje) koji su direktna posljedica intenzivnog jezičkog kontkta s engleskim u proteklih 30 godina u $\mathrm{BiH}$. Takozvano kopiranje identične struture engleskih kompleksnih složenica u maternji jezik se vrlo često ne preporučuje. Za više informacija
} 
U skladu sa svim što je do sada rečeno, tvorba složenica općenito je, a samim tim i složenih imenica, u bosanskom/hrvatskom/srpskom jeziku mnogo je kompleksnija, što se, ilustrativno, može prikazati na sljedeći način:

Engleski: song + writer $>$ songwriter

Bosanski/hrvatski/srpski: tekst + pisac $>$ tekstopisac

Engleski: fire + man $>$ fireman

Bosanski/hrvatski/srpski: vatra + gasiti $>$ * vatragasiti; vatra $+*$ gasac $>$

*vatragasac, ali vatr-o-gas-ac

\section{O PREVODNIM EKVIVALENTIMA ENGLESKIH SLOŽENIH IMENICA}

U skladu sa svim što smo do sada spomenuli, u nastavku ćemo se osvrnuti i na način realizacije engleskih složenih imenica na bosanski/hrvatski/ srpski. Radi lakše preglednosti, engleske složene imenice smo klasificirali u nekoliko grupa, odnosno prema vrsti upravnog člana i broju (nizu) imenica. $^{18}$

\section{$\underline{\text { I Složene imenice s upravnim članom koji je prosta imenica }}$}

(1) bedtime $>$ vrijeme za spavanje

(2) lunchroom $>$ sala za ručavanje

(3) doghouse $>$ kućica za pse

(4) sewing machine $>$ mašina za šivanje/šivaća mašina

(5) driving licence > vozačka dozvola

$\underline{\text { II Složene imenice s upravnim članom koji je imenica izvedena iz glagola }}$

a) sa nastavkom -er

(6) truck driver > vozač kamiona

(7) song writer $>$ tekstopisac

vidi: Jensen, 2015. Također, kao posebna problematika s ovim primjerima nameće se potreba standardizacije prevodnih ekvivalenata, što nikako ne bi trebala biti odluka pojedinca (Sarajevo Film Festival ili Sarajevski filmski festival). op. a.

${ }^{18}$ Primjeri navedeni u ovom radu preuzeti su iz neobjavljenog magistarskog rada autorice. Korpus magistarskog rada sačivanja 2000 engleskih složenica prikupljenih iz Collins WorldBanks korpusa (56 miliona riječi), dok je u magistarskom radu obrađeno ukupno 500 primjera. Za više informacija vidi: Okičić, 2008. 
(8) housekeeper $>$ kućepazitelj

(9) pot-smoker $>$ osoba koja puši marihuanu *pušač marihuane ${ }^{19}$

(10) dog-walker > osoba koja šeta psa * (?) šetač psa ${ }^{20}$

b) sa nastavkom - ing:

(11) fund raising $>$ prikupljanje sredstava

(12) confidence-building ${ }^{21}>$ sticanje/izgradnja povjerenja

(13) decision-making $>$ donošenje odluka

(14) budget planning $>$ planiranje budžeta

Ukoliko se osvrnemo na navedene primjere, može se zapaziti da se kao najtipičniji prevodni ekvivalent pojavljuje imenička sintagma. Ova vrsta prevodnog ekvivalenta je i jedini prevodni ekvivalent za engleske složene imenice koje nastaju nizanjem triju i više imenica.

\section{Niz od tri imenice}

(15) London Fashion Week > Londonska sedmica mode

(16) Cannes Film Festival > Filmski festival u Kanu

(17) Asia Research Centre > Azijski istraživački centar

(18) George Washington University Hospital > Univerzitetska bolnica "Džordž Vašington"

(19) Pentagon Security Policy $>$ Siguronosna politika Pentagona

(20) Blood Transfusion Centre $>$ Centar za transfuziju krvi

(21) Service Delivery Centre $>$ Centar za pružanje usluga

(22) Youth Juvenile Centre > Centar za maloljetne delikvente

(23) Family Insurance Society $>$ Centar za osiguranje porodice

(24) Forestry Protection Society > Društvo za zaštitu šuma

(25) Democratization Department Director > Direktor Odjela za demokratizaciju

(26) Road Safety Advisor > Savjetnik za sigurnost na putu/putevima

\footnotetext{
${ }^{19} \mathrm{U}$ ovoj situaciji zanimljivo je primijetiti da se na bosanskom/hrvatskom/srpskom jeziku mora upotrijebiti imenica "osoba", čime se izražava vršilac radnje koji se u engleskom izražava nastavkom -er (pri čemu u bosanskom/hrvatskom/srpskom jeziku za ovakve imenice nema adekvatnog prevodnog ekvialenta kao jedna riječ) op. a.

${ }^{20} \mathrm{U}$ posljednje vrijeme se može primijetiti upotreba ovog izraza kao vrste honorarnog posla. op. a.

${ }^{21}$ Primjeri napisani u obliku u kojem su zabilježeni u korpusu. op. a.
} 
(27) Network System Administrator $>$ Administrator računarskih mreža

(28) Assistant State Secretary > Pomoćnik Državnog sekretara

$\underline{\text { IV Niz of četiri imenice }}$

(29) Tokyo Earthquake Prediction Centre > Tokijski centar za predviđanje zamljotresa

(30) Kansas Dog Adoption Centre > Centar za usvajanje pasa u Kansasu

(31) NASA Kennedy Space Centre > NASA Svemirski centar «Kenedy»

(32) Family Violence Prevention Centre $>$ Centar za prevenciju nasilja u porodici

(33) Community Development Project Assistant $>$ Asistent na projektu za razvoj lokalnih zajednica

(34) Tobacco Control Project Assistant > Asistent na projektu za kontrolu duhana

(35) Corporate Development Programme Manager $>$ Menadžer programa za korporacijski razvoj

$\underline{\text { V Niz od pet imenica }}$

(36) Harvard Youth Violence Prevention Centre $>$ Harvardski centar za prevenciju nasilja među omladinom

(37) London Business School Student Association > Udruženje studenata Londonske poslovne škole

(38) Napa Valley Grape Growers Association > Udruženje uzgajivača grožđa iz Napa Doline

Analizom spomenutih primjera dolazimo do zapažanja da se kao najfrekventnije strukture putem kojih se realiziraju prevodni ekvivalenti pojavljuju imeničke sintagme u kojima je upravni član: ${ }^{22}$

1) postmodificiran prijedložnom sintagmom (vrijeme za spavanje, Centar za transfuziju krvi)

2) predmodificiran pridjevom (Azijski [istraživački centar])

3) postmodificiran imenicom (donošenje odluka)

${ }^{22}$ Opis sintagmi u skladu s terminologijom koja se koristi za opis sintagmi u engleskom jeziku. op. a. 


\section{ZAŠTO IMAMO PROBLEM S ENGLESKIM SLOŽENIM IMENICAMA I KADA ZNAMO KAKO SE PREVODE?}

Iako smo u prethodnom dijelu rada ukazali na važne razlike između morfoloških sistema engleskog i bosanskog/hrvatskog/srpskog jezika, ovdje je potrebno istaći još nekoliko veoma važnih detalja koji su itekako relevantni za ovu temu. S tim u vezi, važno je napomenuti da se jezičke situacije poput ove koja je opisana u ovom radu, danas sve više objašnjavaju, ne samo iz ugla "čistokrvne" gramatike i kontrastivnih razlika, već i iz ugla teorije usvajanja stranog jezika (engl. foreign language acquisition). Oblast usvajanja stranog jezika relativno je mlada disciplina, ali tema transfera (engl. transfer) poprilično je obrađena. ${ }^{23}$ Najjednostavnije rečeno, kada učimo neki strani jezik, jedna od najčešćih pojava je da mislimo na maternjem (engl. source language (L1), a taj isti tok misli pokušavamo izraziti na stranom jeziku (engl. target language (L2) kojeg učimo. U takvom procesu koristimo sva stečena znanja iz maternjeg jezika koja (svjesno i nesvjesno) "prebacujemo" u strani jezik. Neke od takvih posljedica mogu biti pozitivne, pa se tako govori o pozitivnom transferu (engl. positive transfer). Naprimjer, pod pozitivnim transferom na relaciji bosanski/hrvatski/srpski - engleski može se izdvojiti činjenica da i jedan i drugi jezik imaju sadašnje vrijeme (prezent), ali se pod negativnim trasferom izdvaja činjenica da engleski ima četiri sadašnja vremena. Sa druge strane, neka doslovna prenošenja iz maternjeg na strani jezik mogu izazvati negativne posljedice (greške). Tipični primjeri u kontekstu odnosa bosanski/hrvatski/srpski engleski veoma su vidljivi na planu vokabulara. Naprimjer, dok je u bosanskom/hrvatskom/srpskom jeziku imenica informacija brojiva, to nije slučaj s engleskim jezikom. Kao posljedica takve situacije, kod govornika kojima je bosanski/hrvatski/srpski maternji jezik često se susreće upotreba oblika imenice *informations prilikom usmenog i pismenog izražavanja. Ista situacija susreće se i s imenicom advice (savjet - savjeti) u obliku *advices (savjet $>$ savjeti), s imenicom evidence (dokaz, dokazi) $>$ *evidences, itd.

Sve navedeno ima itekako uticaja na proces usvajanja engleskih složenih imenica. Drugim riječima, s obzirom na to da složenice nisu osobito produktivne u bosanskom/hrvatskom/srpskom jeziku, prilikom izražavanja na engleskom jeziku veoma često dešava se to da se sa bosanskog/hrvatskog/

${ }^{23}$ Za više informacija vidi: Gass i Selinker, 2008; Ellis, 1994. 
srpskog na engleski "prenosi” bukvalan redoslijed riječi, pa se tako češće čuju riječ-po-riječ opisne sintagmatske formulacije u funkciji prevodnog ekvivalenta. Naprimjer, ako se u bosanskom/hrvatskom/srpskom jeziku kaže kućica za pse ili vrijeme za spavanje, veoma često dolazi do identičnih riječ-po-riječ formulacija prilikom izražavanja na engleskom jeziku: $a$ house for dogs umjesto (a) doghouse. Situacija se posebno usložnjava ako imamo nešto duži niz, pa se tako, naprimjer, prilikom izražavanja značenja izraza Asistent na projektu reforme obrazovanja, veoma često dobiju rješenja poput poput Assistant working on the project which is about/deals with the reform of education, umjesto Education Reform Project Assistant.

S tim u vezi, u literaturi koja se bavi problematikom podučavanja kontrastivnih razlika oduvijek se govori o potrebi (ili suvišnosti) upotrebe maternjeg jezika u nastavnom procesu. Ključna ideja ogleda se u činjenici da bi se, ukoliko se onima koji usvajaju strani jezik pomogne u smislu osvještavanja kontrastivnih razlika, moglo doći do boljih rezultata u pogledu korištenja istih. O tome postoje mnogobrojne studije, pri čemu neki autori smatraju da bi u ovom kontekstu upotreba maternjeg jezika bila "najnormalnija stvar" (Ur, 2016; Mitchell i Myles, 2004; Grasso, 2012), dok neki drugi smatraju da se upotreba maternjeg jezika treba svesti na pažljivo osmišljenu strategiju koja bi se trebala realizirati pod tačno određenim uslovima (Harbord (1992), Jan, Li \& Lin, 2014; Attkinskon, 1993; Scrivener (2005)). Sa druge strane, postoje i autori koji se oštro protive bilo kakvoj upotrebi maternjeg jezika tokom podučavanja stranog, bez obzira o kojoj temi je riječ (Paker i Karaağaç, 2015, Georgiana, 2017).

\section{ZAKLJUČAK}

Imajući u vidu sve što je rečeno u ovom radu, može se zaključiti sljedeće. Razlika u pogledu stepena produktivnosti slaganja u engleskom i bosanskom/hrvatskom/srpskom jeziku direktna je posljedica različitih morfoloških sistema ova dva jezika. Ono što se izdvaja kao veoma očit zaključak je da što je padežna paradigma bogatija u pogledu flektivnih nastavaka, stepen produktivnosti slaganja je niži, i obratno. Sa druge strane, nema nimalo sumnje da složene imenice predstavljaju poseban izazov u pogledu podučavanja. U tom smislu bilo bi korisno ovakvu i slične kontrastivne razlike pokušati osvijestiti kroz upotrebu maternjeg jezika i pažljivo 
osmišljenih (kraćih) pojašnjenja i dobrih primjera. Drugim riječima, bilo bi korisno upoznati sve one koji pokušavaju naučiti engleski jezik zbog čega nam se ovakve situacije dešavaju i zbog čega griješimo, pojasniti šta je pozitivni, a šta negativni transfer te na konkretnim primjerima pokušati osvijestiti ovu problematiku s ciljem što efikasnije primjene teorije u praksu. Potvrđivanje ovakvih pretpostavki podrazumijeva realiziranje istraživanja s reprezentativnim uzorkom ispitanika, koje bi bilo uobličeno u ozbiljniji metodološki okvir te u formi preporuke za buduća istraživanja, ovaj rad služi i kao poziv svima onima koji su u svojoj dosadašnjoj praksi prepoznali izazov podučavanja engleskih složenica općenito.

\section{LITERATURA}

Atkinson, D., 1993. Teaching Monolingual Classes. Harlow: Longman Group UK.

Barić, E. et al., 1995. Hrvatska gramatika. Zagreb: Školska knjiga.

Bauer, L., 1983. English word-formation. Cambridge: Cambridge University Press.

Bauer, L., 2003. Word-formation in English. Cambridge: Cambridge University Press.

Babić, S., 1986. Tvorba riječi u hrvatskom književnom jeziku. Zagreb: Školska knjiga.

Booij G., 2005. The Grammar of Words. Oxford: Oxford University Press.

Eckersley, C.E., Eckersley, J.M., 1997. 12 ${ }^{\text {th }}$ ed. A Comprehensive English Grammar for Foreign Students. Essex: Longman.

Ellis, R.,1994. The study of second language acquisition. Oxford: Oxford University Press.

Fabb, N., 1998. "Compounding”. The Handbook of Morphology, str. 66-83.

Gass, S. M., Selinker, L., 2008. Second language acquisition: An introductory course. New York: Routledge.

Georgiana, C., 2012. "Overusing mother tongue in English language teaching". Cultural and Linguistic Communication, 2(3) (July - September), str. 212-218.

Grasso, S., 2012. "L1, or no L1: that is the question." How do we reconcile the ethical implications of this issue in the context of the adult ELICOS classroom? TESOL in Context, Special Ed (November), str. 1-13.

Harbord, J., 1992. "The Use of the Mother Tongue in the Classroom". ELT Journal, 46(4), str. 350-355. 
Haspelmath, M., 2002. Understanding Morphology. London: Arnold.

Jahić, Dž., Halilović, S., Palić, I., 2000. Gramatika bosanskoga jezika. Zenica: Dom štampe.

Jan, C. W., Li, B. J., Lin, C. C., 2014. "The use of the mother tongue in Chinese EFL classrooms". Journal of China University of Science and Technology, 58(1), str. 161-181.

Jensen, N. M., 2015. "Optimising comprehensibility in interlingual translation: The need for intralingual translation". U: Maksymski, K., Gutermuth, S. Hansen-Schirra, S. ur. Translation and Comprehensibility. Berlin: Frank \& Timme, str. 163-194.

Katamba, F., 1993. Morphology. Basingstoke, Hampshire: Macmillan Press.

Klajn, I., 2002. Tvorba reči u savremenom srpskom jeziku. Deo 1, Slaganje i prefiksacija. Beograd: Matica srpska.

Klajn, I., 2005. Gramatika srpskog jezika. Beograd: Zavod za udžbenike i nastavna sredstva.

Lieber, R., 2004. Morphology and Lexical Semantics. Cambridge: Cambridge University Press.

Matthews, P. H., 1991. Morphology (Cambridge Textbooks in Linguistics), $2^{\text {nd }}$ ed. Cambridge: Cambridge University Press

Marković, I., 2012. Uvod u jezičnu morfologiju. Zagreb: Disput.

Mitchell, R., Myles, F., 2004. Second language Learning Theories, $2^{\text {nd }}$ ed. London: Arnold.

Okičić, M., 2008. Kontrastivna analiza složenica u engleskom i bosanskom jezi$k u$. Magistarski rad. Univerzitet u Sarajevu.

Olsen, S., 2000. “Composition”. U: Booij, F., Mugdan, J. i C. Lehmann, ur. Morphologie - Morphology, Berlin, New York: De Gruyter Mouton, str. 879-916.

Paker, T., Karaağaç, Ö., 2015. "The use and functions of mother tongue in EFL classes". Procedia-Social and Behavioral Sciences, 199, str. 111-119.

Plag, I., 2003. Word-formation in English. Cambridge: Cambridge University Press.

Quirk, R. et al., 2004. A comprehensive grammar of the English language, $11^{\text {th }}$ ed. London: Longman.

Riđanović, M., 1998. Jezik i njegova struktura. Sarajevo: Svjetlost

Riđanović, M., 2007. Praktična engleska gramatika. Sarajevo: Šahinpašić.

Riđanović, M., 2012. Bosnian for Foreigners with a comprehensive grammar. Sarajevo: Rabic Publishing Company. 
Scalise, S., Guevara, E., 2006. "Exocentric Compounding. Lingue”. Linguaggio, Vol. V-II, str. 185-206.

Scrivener, J., 2005. Learning Teaching, $2^{\text {nd }}$ ed. Oxford: MacMillan Education.

Ur, P., 2016. Penny Ur's 100 Teaching Tips. Cambridge: Cambridge University Press.

Vukičević, D., 1995. “O značenju imeničkih složenica”. Zbornik Matice srpske za filologiju i lingvistiku, Vol. 37, str. 145-149 


\title{
WHY WE STRUGGLE WITH THE ACQUISITION OF ENGLISH NOMINAL COMPOUNDS - A FEW REMARKS FROM THEORY AND PRACTICE
}

\begin{abstract}
Summary
The paper deals with the problem of poor acquisition of English nominal compounds in EFL university students who are native speakers of Bosnian/Croatian/Serbian (BCS). The problem was tackled by a brief comparison of noun morphology and declension suffixes in English and BCS, the introduction of negative transfer in the process of foreign language acquisition, and the analysis of BCS translation equivalents. The discussion revealed that the productivity of compounding largely depends on the complexity of noun morphology. Put simply, the more complex noun morphology is, the less productive compounding will be. In addition, the analysis of the translation equivalents also highlighted that a vast majority of problems related to poor acquisition of English nominal compounds stems from the fact that EFL learners usually translate L1 phrases word-forword into L2. Finally, it was pointed out that teaching English nominal compounds to EFL learners could be improved by tailored-made instructions provided in L1.
\end{abstract}

Key words: compounding, nominal compounds, translation equivalents, mother tongue, productivity 